\title{
The third International Geological Congress, Berlin (1885)
}

\author{
Octavio Puche-Riart*, José Eugenio Ortiz-Menéndez, and Luis Felipe Mazadiego-Martínez
}

Escuela Técnica Superior de Ingenieros de Minas y Energía, Universidad Politécnica de Madrid, Calle Ramiro de Maeztu, 7, 28040 Madrid, Spain; *Corresponding author, E-mail: octavio.puche@upm.es

The $3^{\text {rd }}$ International Geological Congress (IGC) was held in Berlin (Germany) in 1885. The program focused on four subjects: unifying the representation of European geology, standardizing geological nomenclature, establishing criteria for mineralogical and paleontological nomenclature, and scientific communications and the lastest progress in Geology. During the Congress important discussions about geological representations and terminology took place.

\section{Preparations for the Berlin IGC}

According to some sources, the IGC was initially conceived during the $25^{\text {th }}$ Meeting of the American Association for the Advancement of Science in Buffalo, New York, on 25 August 1876 (Vai, 2004). During that event a formal proposal was made to hold an International Congress of Geologists in Paris to coincide with the Universal Exhibition in 1878 (Ellenberger, 1999). However, the idea of holding the IGC in Paris had apparently originated in 1876 at the International Centennial Exhibition held in Philadelphia from 10 May to 10 November. European and American geologists who met there agreed to set up a commission to organize the Paris Congress of 1878 (Firket, 1885). In 1876 the Spanish geologist Juan Vilanova y Piera (1821-1893) had proposed the organization of an International Geological Congress to the Société Géologique de France with the aim of establishing standards for geological nomenclature (Ellenberger, 1999). During the Paris IGC (1878) and the following Bologna IGC (1881), the standardization of the representation of geology and of mineralogical, paleontological and stratigraphic nomenclature was addressed, as well as the standardization of geological maps (Dewalque, 1885; Firket, 1885; Ellenberger, 1999; Vai, 2004).

At the Bologna IGC it was decided that the $3^{\text {rd }}$ Congress would be held in Berlin in 1884, chaired by Heinrich Ernst Beyrich (18151896). In August 1883 Beyrich presented the project to the Deutsche Geologische Gesellschaft assembled in Stuttgart, proposing the creation of the organizing committee of the IGC. This body, which gathered in December, was comprised of the following members:

- President: Heinrich Ernst Beyrich, professor of geology and paleontology at the University of Berlin; co-director of the Prussian Geological Survey.

- Honorary President: Ernst Heinrich Karl von Dechen (18001889) former chief of the Prussian Mining Service.

- Secretary: Heinrich Lambert Wilhelm Hauchecorne (1828-1900), director of the Berlin School of Mines.

- Financial officer: Gottlieb Michael Berendt (1836-1920), professor at the University of Berlin and chief geologist of the Prussian Geo- logical Survey.

- Honorary members: Arnold Heinrich Albert von Maybach (18221904), minister of Public Works; Gustav Konrad Heinrich von Goßler (1838-1902), minister of Religious Affairs and Education; Maximilian Franz August von Forckenbeck (1821-1892), mayor of Berlin; Gustav Robert Kirchhoff (1824-1887), professor of mathematical physics and rector of the University of Berlin; Emil du Bois-Reymond (1818-1896), professor of physiology and permanent secretary of the Berlin Academy of Sciences; Georg Friedrich Julius Arthur von Auwers (1838-1915), professor of astronomy and permanent secretary of the Berlin Academy of Sciences; Hermann Gustav Settegast (1819-1908), rector of the School of Agriculture in Berlin (Anonymous, 1888).

Also included were several delegates from public administration and a long list of ordinary members, mainly geologists and mining engineers from academia, public institutions, or mining companies.

The committee decided that the $3^{\text {rd }}$ IGC would take place in September 1884 . The program was limited to the topics addressed in the two previous congresses:

1) Standardization of geological representations.

2) Standardization of geological nomenclature.

3) Establishment of criteria for mineralogical and paleontological nomenclature.

4) Communications and scientific discussions.

Furthermore, it was decided to prepare geological collections, together with a sample map, for exhibition in the School of Mines (Fig. 1). The event would also include geological and mining field trips to the Harz, the salt mines of Staßfurt, and other mining exploitations in Saxony.

In May 1884, the organizing committee drew up the first letter or

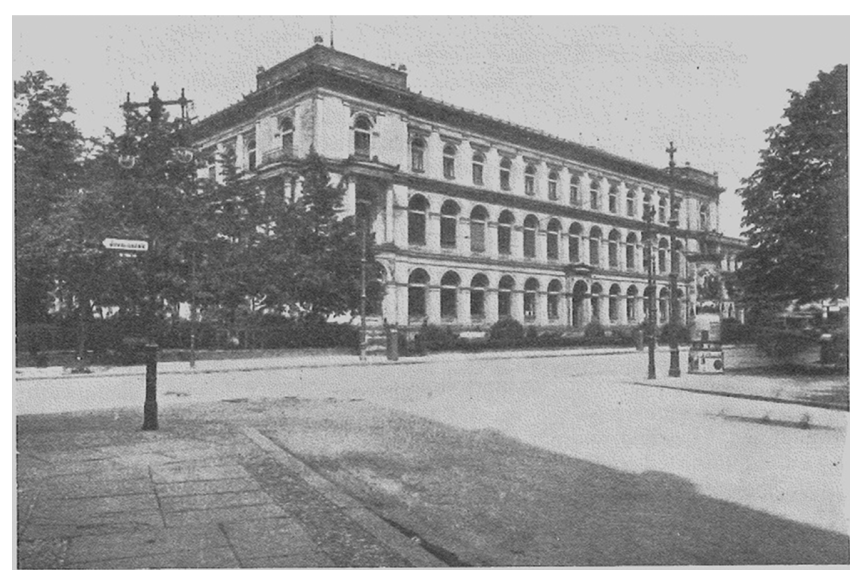

Figure 1. Prussian School of Mines. 
circular, which provided basic information, including the dates of the event (25-30 September) and registration fee (10 Marks or 12 French Francs). In July of the same year, the President of the Bologna IGC, Giovani Capellini (1833-1922), proposed that the $3^{\text {rd }}$ IGC be postponed until 1885 because of a cholera epidemic affecting the south of Europe, mainly France, Spain and Italy (McKenny Hughes, 1884). This proposal was accepted by the committee and, the $3^{\text {rd }}$ IGC was delayed by a year. A letter or circular communicating the change of dates went out in July 1884 .

The final letters of invitation to the IGC were sent on 15 April 1885, indicating that the Congress would be held from 28 September to 3 October and that the field trips would take place from 5 to 10 October. The program and regulations were announced on July $15^{\text {th }}$. The Council of the $3^{\text {rd }}$ IGC was composed of the organizing committee, presidents of geological companies, the Congress office, etc. The Congress office would be responsible for planning the daily schedule of events. October $4^{\text {th }}$ was reserved for a trip to the nearby city of Potsdam. During the Congress, free time was also set aside for visits to museums.

\section{Beginning of the Congress}

As of September $15^{\text {th }}$, the offices of the IGC opened. Those wishing to attend the Congress were able to register at the Geological Survey of Prussia (Preussische Geologische Landesanstalt) and School of Mines (Preussische Bergakademie) (Fig. 1), where they received the conference documents and a medal bearing the IGC emblem (crossed hammers) and motto (Geologorum Conventus mente et malleo) on the front and "Berlin 1885" on the back. On Monday 28 September the office of the IGC moved to the Palace of Parliament (Reichstag) at Leipziger Straße 4 (Fig. 2), where the Advisors met at 11 a.m. about the first day's program. At 5 p.m. the members gathered in the Meeting Room of the Parliament to exchange information.

The Congress involved the participation of 255 geologists: 163 from Germany, 18 from Italy, 16 from the Austro-Hungarian Empire, 11 from Great Britain, 10 from France, 9 from the USA, 6 from Belgium, 6 from Russia, 3 from Sweden, 3 from Switzerland, 2 from Nor-

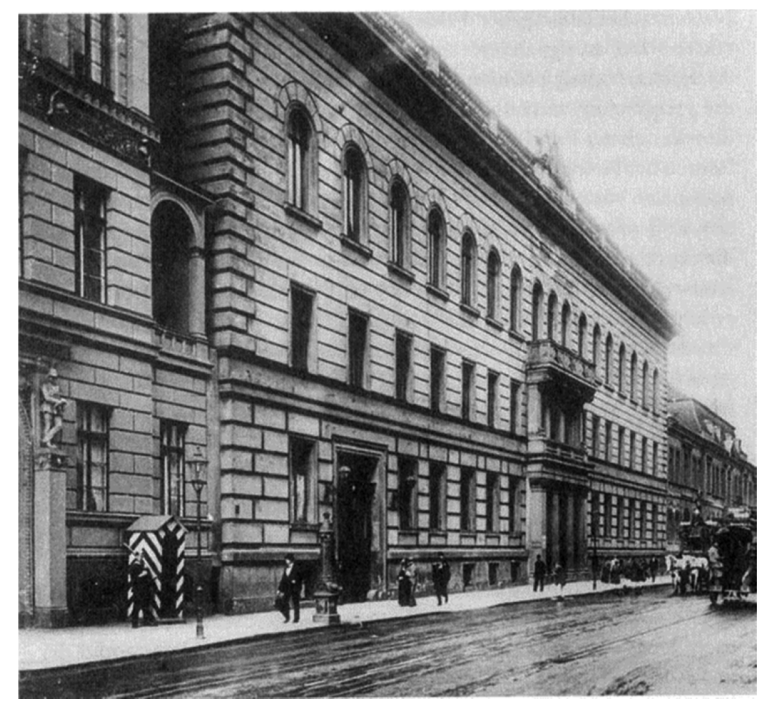

Figure 2. Palace of Parliament (Reichstag). way, 2 from The Netherlands and 1 each from Brazil, Spain, India, Japan, Portugal and Romania (Firket, 1885).

The geologist and former professor of chemistry at the University of Pennsylvania Persifor Frazer (1844-1909) (1886a), citing a report by the Swiss geologist Paul Choffat (1849-1919), gave the following statistics of participants in previous ICGs:

- Paris (1878): 194 French nationals and 110 non-French nationals (304 participants), representing 20 countries.

- Bologna (1881): 149 Italian nationals and 75 non-Italian nationals (224 participants), representing 16 countries.

- Berlin (1885): 163 German nationals and 92 non-Germans nationals (255 participants), representing 17 countries.

These numbers do not coincide with those given in the General Proceedings of the $30^{\text {th }}$ International Geological Congress, Beijing, China (Anonymous, 1997).

The official language of the Berlin IGC was French, although many of those present, mainly the Germans, did not speak that language. The following comment appeared in Nature: "The use of French as the language of discussion was no doubt one effective cause of silence on the part of many members who would otherwise only too readily have made themselves heard" (Anonymous, 1885).

The official inauguration of the IGC took place at the Reichstag on Monday 28 September at 11 a.m. under the presidency of Capellini (Fig. 3a), who was flanked on the right by von Dechen (Fig. 3b) and Hauchecorne (Fig. 3c) and on the left by Beyrich (Fig. 3d) and the North American geologist James Hall (1811-1898) (Fig. 3e). Hall was one of the vice-presidents of the IGCs of Paris, Bologna and Berlin, as well as president of the IGC founding committee. Members of the IGC administration, diplomats, and representatives of the different countries were seated on nearby benches.

Capellini presented Gustav von Goßler (Fig. 3f), who spoke in German to welcome those present to the Congress and to the city of Berlin. Von Goßler referred to the interrelationship of all the sciences and
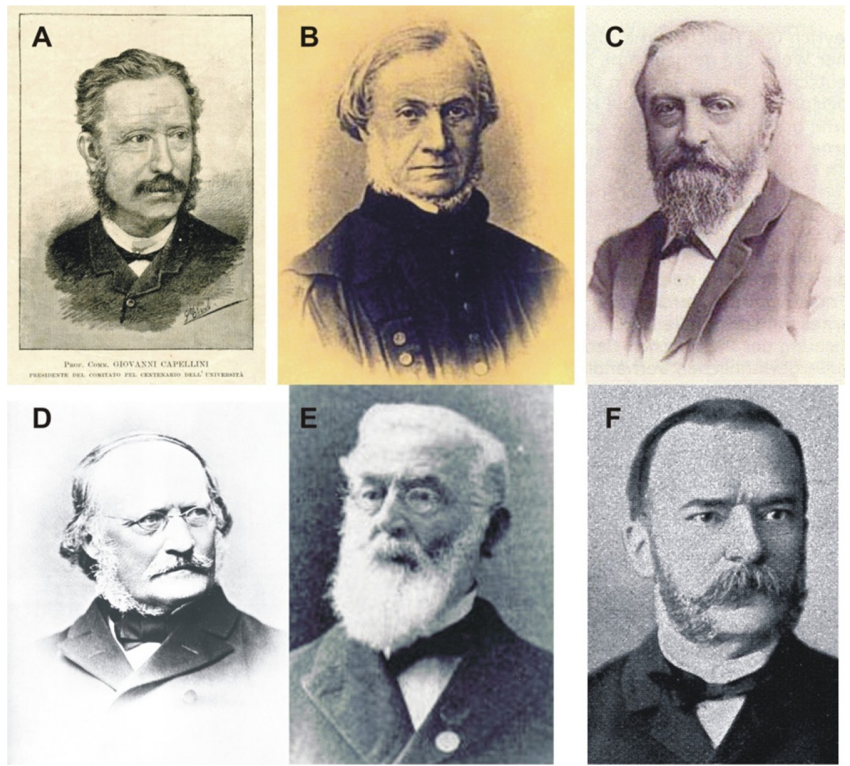

Figure 3. A: Giovanni Capellini; B: Heinrich Karl von Dechen; C: Heinrich Hauchecorne; D: Ernst Beyrich; E: James Hall; F: Gustav von Goßler. 
to Prussia's history as a land of great geologists. He expressed gratitude in the name of the Prussian government for the choice of Berlin as the venue of the IGC. He saluted the audience with the German miners' greeting: "Glück Auf".

Speaking later on, von Dechen remembered the recently deceased Italian professor of mineralogy and vice-president of the Bologna IGC, Quintino Sella (1827-1884). He also mentioned the great men of this science, such as Georges Cuvier (1769-1832), Alexandre Brongniart (1770-1847), Louis Cordier (1777-1861), William Buckland (1784-1856), William Conybeare (1787-1857), George Bellas Greenough (1778-1855), William Henry Fitton (1780-1861), etc., whom he had known during his 60 years of geological work. He said that for many years his models had been Leopold von Buch (17741853) and Alexander von Humboldt (1769-1859).

Von Dechen also discussed the agreement by the Bologna IGC to develop the Geological Map of Europe and the formation of a Commission, headed by Beyrich and Hauchecorne. The Commissions of the Geological Map of Europe and of Nomenclature had since been very active: they had met in conjunction with a meeting of the Société géologique de France in Foix (1882) and the Naturforschende Gesellschaft in Zürich (1883). Great advances had been made, he said, on the topographic base map. The decisions made during the Bologna IGC had been applied to the first edition of the map; the standardization of figures and nomenclature were therefore an urgent necessity. He also mentioned the Diccionario Geográfico-Geológico by the Spanish geologist Juan Vilanova y Piera and the Nomenclator Palaeographicus by geologist and professor at the University of Vienna Melchior Neumayr (1845-1890). He ended by wishing the Congress: "Glück Auf".

In his speech, Beyrich recalled that Germany was the native country of Abraham Gottlob Werner (1749-1817), von Humboldt, and von Buch. He also mentioned all the work done to organize the IGC, remarking upon the support received from the German authorities, as well as from geological and mining institutions. After recalling the origin and accomplishments of the previous IGC, he pointed out the importance of the topics to be debated and the agreements to be reached during the Berlin IGC, especially regarding the production of the Geological Map of Europe. He said that professor of chemistry and physics at the University of Liège and president of the Academy of Sciences of Belgium Gilles Joseph Gustave Dewalque (1826-1905) and the Swiss geologist and professor of sciences at the Academy of Lausanne Eugène Renevier (1831-1906), would be in charge of presenting the resolutions of the commissions for ratification. Regarding the paleontological nomenclature presented by Neumayr, he mentioned that the biological and botanical societies had been invited to participate in a committee of nomenclature. He also mentioned the importance of the geological dictionary to be presented during the Congress by Vilanova y Piera.

Capellini expressed gratitude to the German authorities for their interest in the ICG. He proceeded to the election of the members of the congress office. The list of members presented was approved unanimously.

The opening of the geological exhibition organized for the Berlin IGC took place in the Geological Survey of Prussia and Berlin School of Mines at 2 p.m. The Mineralogical Museum of the Polytechnic School at Charlottenburg and the mineralogical collections of the School of Agriculture were also visited on other days. In the School of

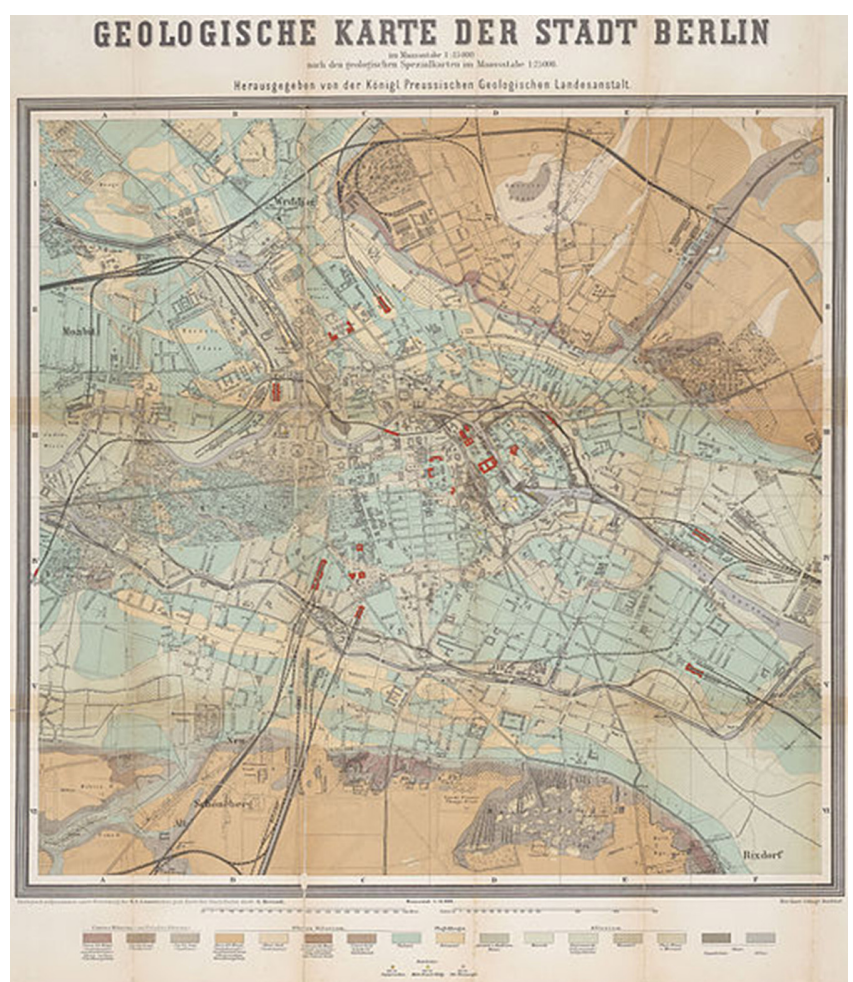

Figure 4. Geological map of Berlin, 1885.

Mines an important space was dedicated to geological cartography. The IGC received the Geologische Karte der Stadt Berlin (Geological Map of the City of Berlin) at the scale of 1:15.000 as a gift (Fig. 4). The IGC also received a catalogue of the mineralogical collections of the Polytechnic School at Charlottenburg and the guide to the Royal Museums of Berlin for the foreign members. Members were accorded access to various scientific and artistic establishments and given the opportunity to attend the Opera (Choffat, 1885-1887).

\section{The Geological Map of Europe: Colors, Legend and Other Features}

The Bologna IGC had agreed to make a unified Geological Map of Europe at the scale of 1:500.000. The execution of this map was to take place in Berlin (Bouysse, 2103) under the direction of Beyrich and Hauchecorne. During the Berlin IGC standards were to be set for this geological map.

On Tuesday and Wednesday 29 and 30 September at 6 p.m., Renevier (Fig. 5), secretary of the Committee of the Geological Map of Europe, presented all the work done since the IGC of Bologna, relative to:

1) The conditions for publication of the map.

2) The progress of work on the topographic base map.

3) The decisions of the International Commission about the representation of geology.

According to Renevier, a contract with excellent scientific and financial terms had been signed with Reimer and Co. of Berlin for the publication of the map. It would consist of a total of 49 geological sheets (maps), each $48 \times 53 \mathrm{~cm}$, which together would form a rectangle 


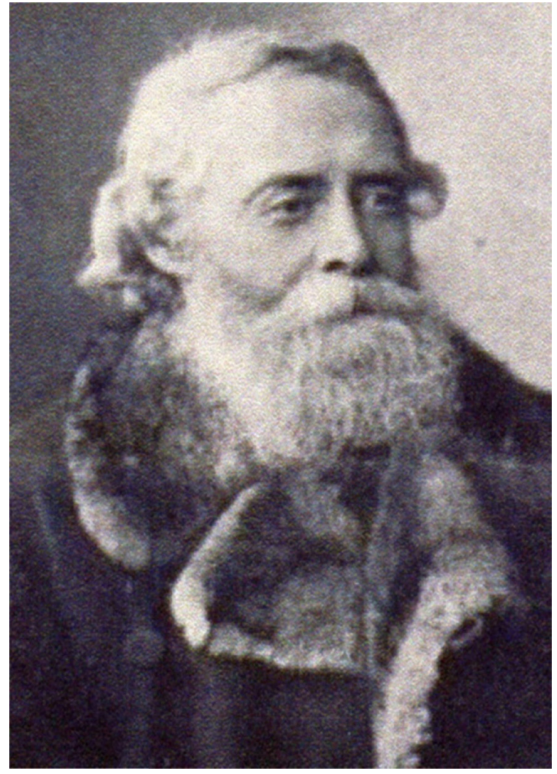

Figure 5. Eugène Renevier.

measuring $3.36 \times 3.72 \mathrm{~m}$. Professor Johann Samuel Heinrich Kiepert (1818-1899) of Berlin was to prepare the topographic base map. The International Commission guaranteed the publication of 900 copies at 100 French Francs per copy. Eight of the larger European nations (Great Britain, France, Spain, Italy, Austria-Hungary, Germany, Scandinavia, and Russia) would each order 100 copies. The six smaller countries (Belgium, Holland, Denmark, Switzerland, Portugal, and Romania) would divide the remaining 100 copies among themselves.

The scale of the map would be of 1:1,500,000. Of the 49 sheets of the topographic base map, 32 were already nearly finished and engraved, pending agreement on whether or not to use abbreviations to label geographical names. The country with the most advanced geological work was Germany. Austria, France and England also brought their maps to the Berlin IGC, whereas the Italians and some other countries attributed their delay to the lack of a good topographic base map.

The Committee of the Geological Map of Europe included geologists and mining engineers from several countries: Germany, Beyrich and Hauchecorne; France, Gabriel Auguste Daubrée (1814-1896); Italy, Felice Giordano (1825-1892); Russia, Valérien von Moeller (1840-1910); Austro-Hungarian Empire, Edmund Mojsisovics (1839-1907); Great Britain, William Topley (1841-1894); and Belgium, Renevier. These men would receive the drafts of maps sent from each country and take charge of harmonizing them to facilitate joining the sheets together. However, the Management Committee of Beyrich and Hauchecorne would actually supervise the work, since both were located in Berlin and were ready to start.

They were building upon the achievements of earlier geologists. Abraham Gottlob Werner (1749-1817) had established the grouping of geological materials into main units according to their characteristics, thus facilitating their cartographic representation. Werner's disciples at the Mining Academy of Freiberg developed maps on which lithologies were represented by different colors. The use of color to represent different lithological units is evident in the maps of Saxony (Johann von Charpentier in 1778), Bavaria (Mathias von Flurl in 1792), and Swiss (Carlos Gimbernat in 1803) (Boixereu, 2016).
Early in 1821 the mining administrator and author, Johann Wolfgang von Goethe (1749-1832) received a request from Christian Keferstein, who was preparing a geognostical General Charte von Deutschland, to establish a uniform scheme of colors for this work (SchäferWeiss and Versemann, 2005). In March 1821 Goethe outlined a chart of colors for this purpose. Thus, thanks to the influence of Werner and Goethe color schemes for lithologies had been established. During the late nineteenth century, when geologists began to use stratigraphical rather than lithological units, the question of color schemes was taken up again in the IGCs of Bologna (1881) and Berlin (1885).

Colors to represent the different geological periods (the most ancient ones being the darkest) had been already chosen in Bologna, but the choice of colors for the ancient rocks, Quaternary deposits and eruptive rocks remained to be made. At the Berlin IGC there was unanimous agreement that eruptive rocks would be represented in seven groups, in different tones of red. Also, there was some discussion about changing to colors easier to interpret: for example, it was suggested that the Cretaceous be represented by green and the Silurian (Cambrian included) by dark green. The members agreed to allow the Commission to make the ultimate decision. In fact, the stratigraphic division of some periods was not clear (for example, joining or separating the Carboniferous and Permian; Permian and Triassic; Silurian and Cambrian; etc.). Therefore, it was considered more important to discuss the geological content of the map legend than to talk about colors.

\section{Stratigraphic Nomenclature}

In the session on Wednesday 3 October and following days of the week, Dewalque (Fig. 6) as secretary of the Commission of Nomenclature announced the agreements reached.

The IGC of Bologna decided to adopt the following stratigraphic divisions: Group, System, Series and, Stage and Assise. The chronological division was: Group, Era, Period, Epoch, and Age. An example would be: Secondary Group, Jurassic System, Liassic Series, Hettangian

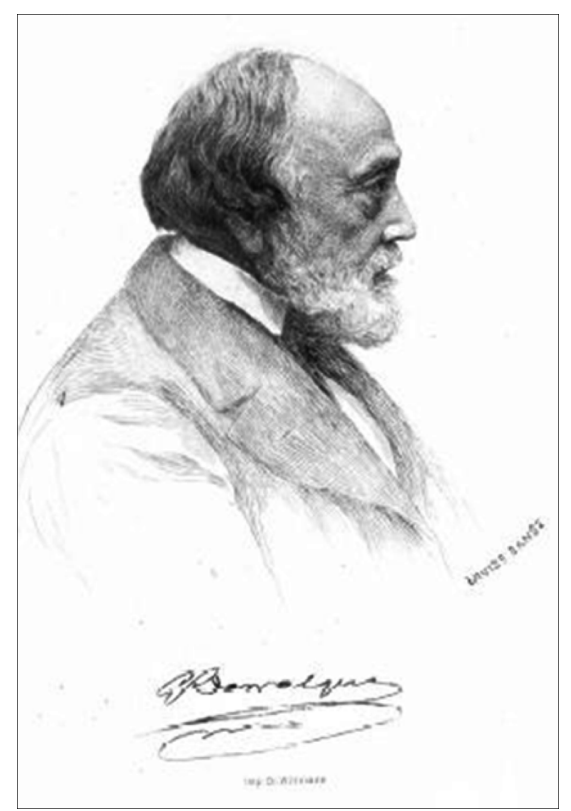

Figure 6. Gilles Dewalque. 
Stage.

Dewalque pointed out that the archaic areas did not belong to the Paleozoic and asked the members if they should be called the Primitive Group. This Group would only contain one Period, the Archaic Period. The British preferred the name Precambrian, the Belgians Cristallophyllien and the Austro-Hungarian Committee Crystalline Stratum. Ultimately, after ample debate it was decided that it would be called the Archaic Group (Archéen).

There was disagreement whether Cambrian and Silurian were to form part of the same Period or whether there would be two different Periods. The Ordovician had been proposed by English geologist Charles Lapworth (1842-1920) in 1879 but his compatriot, geologist John Edward Marr (1857-1933), who had in 1881 objected to the term Ordovician, rejected Lapworth's classification again in Berlin (Bassett, 1979). The Scottish geologist Archibald Geikie (1835-1924) said that this debate was an English question and requested that the controversy be resolved during a Congress in London. Ultimately, the division into Cambrian, Lower Silurian, and Upper Silurian was provisionally adopted, pending modification during the next IGC.

The proposal of the Commission to divide the Devonian into three Series was accepted: Renanian, Eifelian, and Famenian. Strata with calceolas would form part of the Eifelian Series. The difficulties of marking the boundary with the Carboniferous were also mentioned. Dewalque's proposal to link certain English strata, whose contacts were very well marked in the carboniferous limestone with specific horizons on the Continent, was accepted. Thus, the Devonian would contain Condroz's sandstones in Belgium, the Lower Carboniferous of Kiltorcan in Ireland, Marwood in Devonshire or Pilton in North Devonshire, the upper Old Red sandstone from the Orkney Islands, the calcareous sandstone of Dura-Den in Scotland, etc.

During the session on Thursday 1 October Delwaque brought up the agreement made in Zürich to maintain the Carboniferous with its current boundaries, that is to say without including the Permian. This Period would remain divided into two series:

1) The Lower Division (or Bernician, of Bernicia, in the NE of England) that would be formed by the carboniferous limestone (mountain limestone) and the Culm, of Devonshire.

2) The Upper Division (or Colliery), whose bottom begins with the Millstone-Grit (thick sandstones of Northern England).

The Czech geologist Dionýz Stúr (1827-1893), the English naturalist William Thomas Blanford (1832-1905), the French mining engineer Albert Auguste Cochon de Lapparent (1839-1908), and the American geologist John Strong Newberry (1822-1892) spoke in favour of unifying the Permian and Carboniferous, whereas the English geologists Thomas McKenny Hughes (1832-1917) and William Topley, as well as the Russian Sergei Nikolaevich Nikitin (1851-1909), opposed this. After enormous debate, the Congress agreed, provisionally, in order to be able to continue with the production of the map, to separate the Permian from the Carboniferous and from the Triassic. No decision was taken about the name Dyas or Dyasic proposed by some. The German paleontologist Adolf von Koenen (1837-1915) supported the maintenance of the Permian after indicating the existence in the Harz of a clear discontinuity with the Carboniferous. Ultimately, two Series were admitted, but there was no agreement about their names. Beyrich had proposed the names used for the divisions of the Permian in Germany: Rotliegend and Zechstein.
On Friday 2 October, after approval of the new International Commission for the Unification of Geological Nomenclature, the debate about stratigraphic questions continued, particularly regarding the Triassic. Some wanted to join it to the Rhetian, while others said that it should form part of the Liassic. Also debated was whether to divide the Triassic into two Series (one that might be called Pecilian, Conchian or Keuper and the other Vosgian, Wurtzbourgian or Carnian) or into three. Ultimately, they chose three Series, but they decided not to deal with the question of nomenclature.

Discussion of the Jurassic indicated that division into three Series (Lower Jurassic or Liassic, Middle Jurassic or Dogger, and Upper Jurassic or Malm) was universally accepted, although clear agreement about their boundaries had not been reached. The Rethian and the Hettangian were supposed to belong to the Liassic.

With regard to Cretaceous, Dewalque indicated that the decision had been made in Zurich to divide it into two Series: Lower and Upper Cretaceous. It was decided that the Gault (lithological formation whose name comes from the region of Cambridge, Great Britain, and which is synonymous with Albian) should belong to the Lower Cretaceous, in spite of the opposition of the French geologist Edmond Hébert (1812-1890).

With regard to the Tertiary, the question was whether or not to divide it into Groups. In Zürich four divisions had been established, but there was debate about whether there should be three, four or five. Dewalque's assurance that the Map Committee would do everything possible to satisfy everyone was accepted by the majority, in spite of Paul Choffat's protests. The latter later wrote an article "Troisème Séssion du Congrés Géologique International," in the Journal de Sciencias Mathematicas (1885-1887), in which he said: "Quant au Tertiaire, on laisse au directorium la liberté de choisir lui-même le mode de division. Ce sera probablement celui en Eocène, Oligocène, Miocène et Pliocène".

The Quaternary was not discussed. In an oral communication on the last day of the Congress about "Methods of Geologic Cartography in use by the United States Geological Survey" the director John Wesley Powell (1834-1902) considered that the Quaternary should be a part of the Tertiary. This was also contemplated in the "English Report", "French Report," "Portuguese Report," and "Swiss Report" (Reports of the National Committees). Nevertheless in the "Romanian Report" the Quaternary Group was considered to be different from the Tertiary.

Also considered was the division of the magmatic rocks into seven categories: granites, porphyries, trachytes, melaphyres, serpentine, and current lava, as well as tuffs and pyroclasts, in agreement with the scheme of the German mining engineer Karl August Lossen (18411893). It seems that the major petrologists were not consulted: the German Ferdinand Zirkel (1838-1912), the German-Argentinian Alfred Wilhelm Stelzner (1840-1895), the American James Hall, and other geologists. As Gilbert (1887) indicated: "It is conceivable that some benefit might be derived from the submission of the matter to an assembly of specialists". For an important part of the scientific community, it was considered a bad classification (Frazer, 1886a).

Some scientists managed to impose their model. Comparing the legend recommended for the Geological Map of Europe in the Congress of Berlin with that proposed by the Swiss Commission published in Archives des Sciences de Géneve in May 15, 1883 (Fig. 7), it can be observed that differences were small (Renevier, 1886). 
E. KEINEVIEK

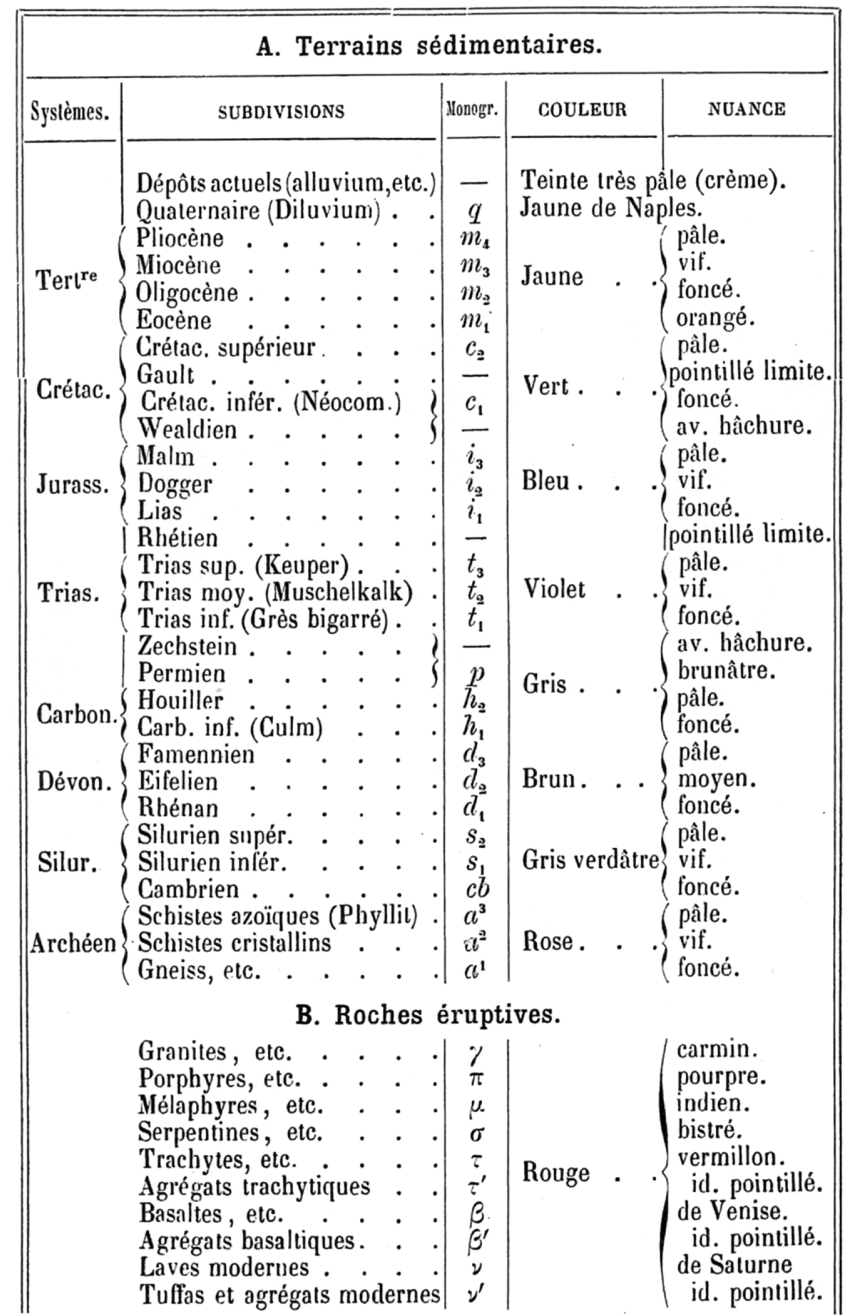

Figure 7. Legend (Stratigraphic divisions and colors) recommended for the Geological Map of Europe proposed by the Swiss Commission.

\section{Palaeontological Nomenclature}

In the Bologna IGC (1881) attention had been paid to the rules of paleontological nomenclature. The members decided to "follow binomial nomenclature and yet at the same time distinguish variability within species attributable to both geographical spread (varieties) and chronological change (mutations)" by a third term (Vai 2004, 18).

During the ICG of Berlin (1885) the offer of the paleontologist Melchior Neumayr to publish the Nomenclator Paleontologicus (Neumayr, 1883) was presented. Neumayr (Fig. 8) was against following the Prodrome de Paléontogie Stratigraphique Universelle (1859) of Alcide de D'Orbigny (1802-1857) in which the different species were described according to geological ages, nor did he agree with the Nomenclator Zoologicus (1848) of Heinrich Georg Bronn (1802-1862), which did not follow any alphabetical order. He proposed citing all the fossils described up to that date, arranged by species and genus. The division of the Nomenclator into volumes would be according to the major divisions

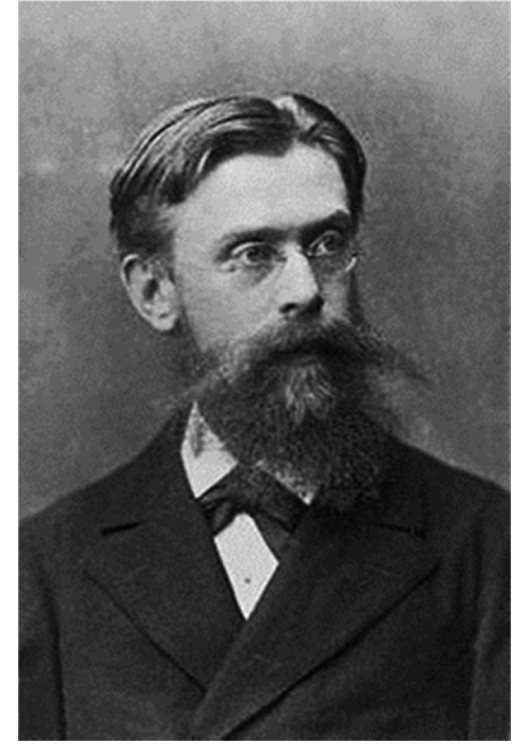

Figure 8. Melchior Neumayr.

of the Animal and Vegetal Kingdoms. Thus, there were volumes devoted to the Protozoan, the Coelenterate (a former class of animals that included the Cnidaria and the Ctenophora), the Vertebrates, the Cryptogams, etc. Classes containing a small number of species would join a neighboring Class, for example Worms and Mollusks. Classes which had expanded greatly, for example Mollusks, would be subdivided. In the first part of each of these volumes the genera and species would appear in alphabetical order, outlining their synonyms. The type localities, deposits, and main publications describing each species would be listed. In the second part, all the names (except synonyms) within zoological or botanical orders would be arranged hierarchically to form a complete and systematic enumeration of every known organism. The publication would consist of 15 volumes totaling 16,000 pages. The introduction, with the information about the collaborators, would be in French, while the language of the body of the Nomenclator would be in Latin. The high price, approximately 200,000 French Francs, of the edition might make it difficult to find a publisher. However, if the IGC were to guarantee the publication, subscriptions by official establishments and scientific societies would be sufficient to make the edition profitable. The goal was to publish the first volume within two or three years and to complete the entire work within ten years.

A work of this magnitude would require at least 30 to 40 collaborators, as well as an editorial committee to assemble the draft. The following members were approved for the committee: the Frenchman Jean Albert Gaudry (1827-1908), the German Karl Alfred Ritter von Zittel (1839-1904), the Englishman Robert Etheridge (1846-1920), and Neumayr.

Among the members there was no unanimous agreement about Neumayr's proposal for the Nomenclator Paleontologicus. Paul Choffat asserted, after returning to Portugal, that catalogued fossils should be mentioned in the stratigraphic division (Choffat, 1855-87). 


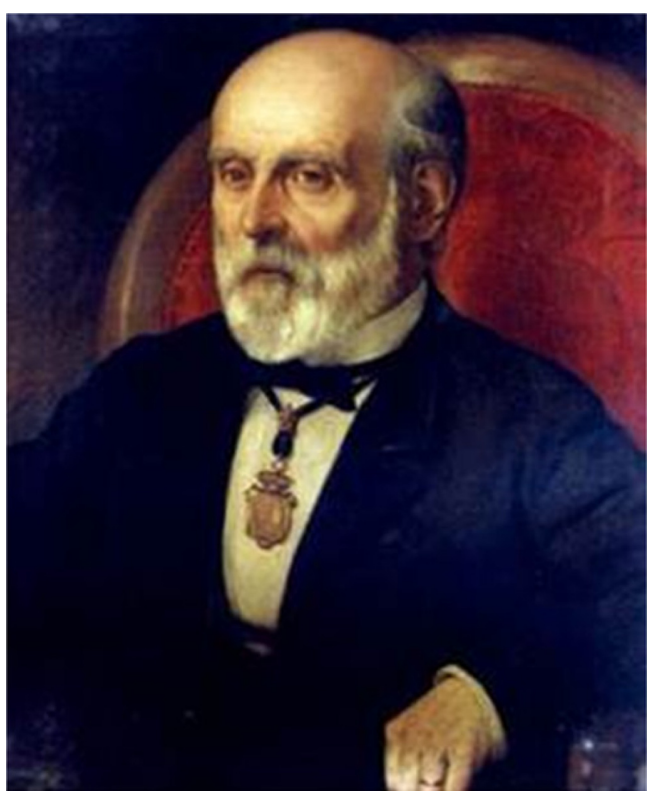

Figura 9. Juan Vilanova.

\section{The Geological Dictionary of Juan Vilanova}

On Saturday 3 October, in the general communications session, Vilanova presented the proposal initiated during the Bologna IGC (1881) of a Dictionary of Physical Geography and of Geology in English, French and Spanish, indicating that he wanted it to be published in all the European languages. During the Congress a Committee, presided by Beyrich, was also approved for the unification of geological terminology.

The French and Spanish parts of the dictionary were finished by Vilanova (Fig. 9) in 1884 and were presented to the Congress. The intention was that Vilanova's work would be improved by others, especially in regard to parallel terms in other languages (Firket, 1885; Frazer, 1886a). Vilanova requested that the assembly decide whether the dictionary should be a simple lexicon including the names of all geological terms in German, English, Russian, etc. or whether a simple definition would be also attached to the etymology. In addition to Vilanova's work, a translation into Hungarian had already been made (Choffat, 1885-87).
Vilanova indicated his hope that this work would be completed in time for the IGC in London (indications were that the next IGC would take place in London). In fact, on the same day, the decision was taken to hold the next IGC in London in 1888, from 15 August to 15 September, and the organizing committee was elected: Geikie, Blanford, Hughes and Topley (Frazer, 1886b).

The request for help to publish 100 copies of the Dictionary was left pending, because the Commissions lacked funds.

\section{Proposal of Creation of an International Geological Society}

In spite of his youth, the Sicilian naturalist Antonio de Gregorio (1855-1930), had been elected a member of the Geological International Commission, in 1884 . He proposed the creation of an international geological society and the publication of a major international geological magazine.

The international geological society proposed at this time and later did not materialize until the International Union of Geological Sciences (IUGS) was created in 1961. The importance of de Gregorio's proposal lies in its priority.

The topic of the magazine was postponed until the next IGC. The reason given by the Organizing Committee of the Congress was that it was not possible to submit to a vote something that had not been previously approved by the Council. Nevertheless, a Commission was formed to work on this topic, composed of Blanford, the French naturalist Charles-François Fontannes (1839-1886), Neumayr, and the Italian geologist Antonio de Gregorio.

The greater part of Saturday 3 October was dedicated to the closing speeches, and no more debates took place.

\section{Field Trips}

In the afternoon on Monday 5 October 104 members met in Thale at the foot of the Harz Mountains. Upon departure from Berlin, they had received a geological map showing the surroundings of Thale at the scale 1:25.000. The paleontologist Wilhelm Dames (1843-1898), professor at the University of Berlin, explained the characteristics of the Triassic and Upper Cretaceous outcrops in the northern area at the

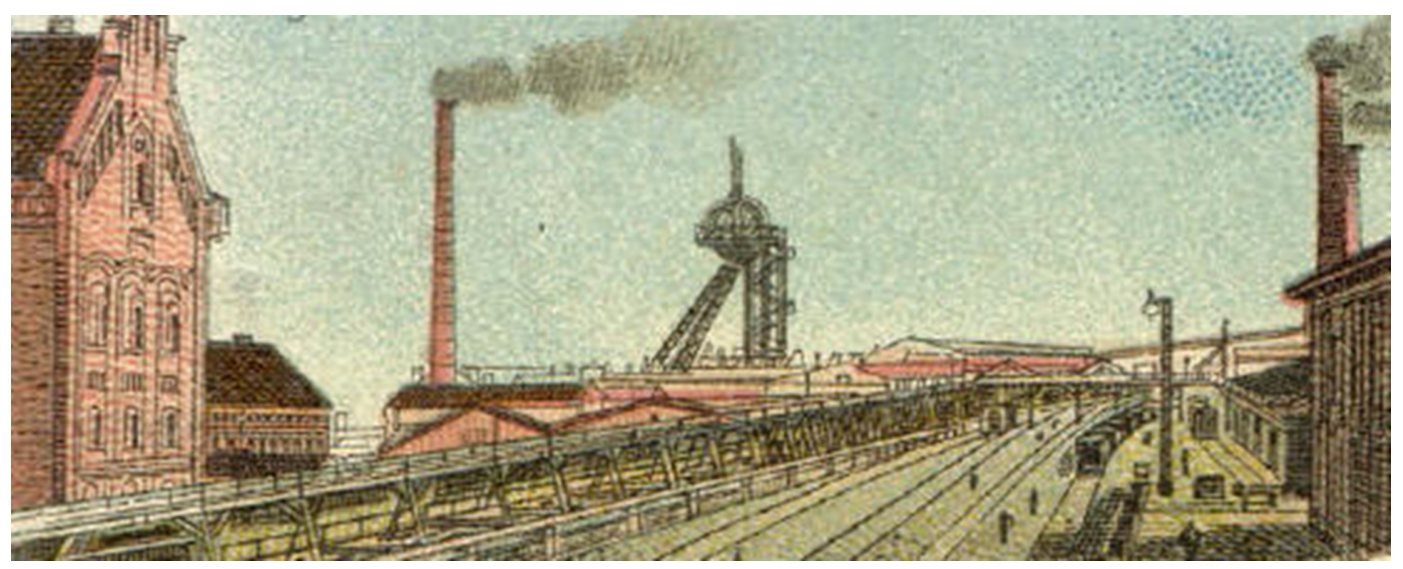

Figure 10. Staßfurt Station (The late XIX Century). 


\section{foot of Harz.}

On 6 October, under the direction of Karl August Lossen (18411893) a petrographic visit was made to Ramberg's granite, a porphyry vein in the Bode Valley (Bode-Gang), the different rocks of the Lower Devonian, as well as the metamorphism of the contact zone and some dikes of diabases.

On 7 October, the tour members visited the royal mines of salt and potash at Staßfurt (Fig. 10), where they were received by the Chief of the Mining District Hermann Freiherr von Heyden-Rynsch (18291917), who explained the geology and the methods of mining this large deposit. The first mine was begun there in 1857. At the time of the 1885 tour there were six important mining works for the exploitation of carnalite and cainite (the visitors toured 3 of these mines). A factory producing potassium chloride would be constructed in 1892 , while manufacture of sulfate began in 1885 in Staßfurt. In 1885 there were 16 factories of chemical products located in Staßfurt, Westeregeln, and Aschersleben. In 1884 the mines had produced 740,000 tons of carnalite and 210,000 tons of cainite, mostly used for fertilizer. In 1885 the local factories generated 120,000 tons of potassium chloride (Firket, 1885).

The next stop of the tour was Leipzig, where the participants could admire the geological collections of the University. In Leipzig the visitors were divided into two groups. One was led by professor and director of the Geological Survey of Saxony Carl Hermann Credner (1841-1913), who organized an itinerary starting north of the city (Taucha, etc.) and then proceeding toward the Erzgebirge (Annaberg, etc.) and Wiesenthal. The other group visited Dresden's surroundings, Plauen's valley, etc., under Hanns Bruno Geinitz's direction (1814-1900). Subsequently, both groups met in Dresden, where Geinitz showed them the mineralogical collections. There the tour ended, and they bade farewell to one another until the London IGC (1888).

\section{Conclusions}

This paper highlights the importance of Berlin IGC (1885), although these early congresses were not meant for general scientific exchange as such, but rather for "administrative" purposes. The main concerns were based on the development of national geological maps or those from the colonies of each country. However, there was not a globalizing identity or interest to universalize and standardize geological knowledge.

Moreover, in the $19^{\text {th }}$ century the possibilities to travel were not easy, i.e., the first cars with gasoline engines were created in 1885 and people traveled by railways and streamboats (between continents): travels were expensive and time consuming and this affected the attendance at congresses.

It must be highlighted that the European Treaty on the division of the provinces of Africa between the European countries took place in 1885. The Berlin Conference, held between 15 November 1884 and 26 February 1885 resolved the problems provoked by the colonial expansion in Africa. It should therefore assume the existence of friction between countries and particularly since the territorial partition of Africa had clear geological and mining interests. The main conclusions are listed below:

- The meetings in Foix and Zürich were preparatory for the Berlin
IGC (1885) (Nery Delgado, and Choffat, 1884) and laid the groundwork for its organization.

- During the Berlin IGC (1885) numerous resolutions were taken about the future Geological Map of Europe. In the end it was agreed to allow the freedom necessary, within the limits of the agreements, for the map project directors to make decisions about minor matters or those not agreed upon by consensus, until the next IGC.

- Many of the geologists present thought that it would be difficult to undo agreements voted in by the majority. Some of them, like Paul Choffat, complained about this manner of working: "Une première erreur $a$ été de commencer la publication d'une carte géologique avant d'avoir fixé les príncipes sur lesquels elle doit reposer" (Choffat, 1855-1857). Others wanted to have the freedom to choose stratigraphic divisions without trying to correlate with those of different countries (Frazer, 1886a). Grove Karl Gilbert (1843-1918) indicated: "There does not exist a world-wide system not a world-wide group, but every system and every group is local. The classification developed in one place is perfectly applicable only there" (Gilbert, 1887).

- In spite of the mistakes, initial agreement upon the standardization of geological maps was reached. In the closing ceremony of the Congress, Capellini recalled the lengthy discussions dedicated to representation and terminology of geology, indicating that: "le congrés a voté plusieurs resolutions importantes et a decidé qu'une carte géologique d'Europe será exécutée à Berlin" (Anonymous, 1888). According to Frazer (1886a): "much could be done and indeed has been achieved...", indicating that part of the delay in this century was due to conflicts on minor matters of the nomenclature, classification and units.

- The summary of topics approved in Berlin was to be presented by Persifor Frazer to the American Committee (Anonymous, 1885). This Committee gave its approval for the agreements made during the Berlin IGC (1885), urging that work proceed on that basis. The American Committee also proposed to maintain the term Étage (Stage) (Frazer, 1886b). With the acceptance of the stratigraphic nomenclature on both sides of the Atlantic Ocean, the Commission of the Geological Map of Europe established the precedent for the Commission of the Geological Map of the World. That project would be considered at the $11^{\text {th }}$ IGC (Stockholm, 1910) and approved at the $12^{\text {th }}$ IGC (Toronto, 1913).

- There were other agreements, as well as to paleontological nomenclature and geological terminology.

- The minutes of the Berlin IGC were published in 1888 after a delay of three years.

\section{Acknowledgements}

We would like to express thanks for the support and helpful comments of the late Prof. David Oldroyd, Prof. Karen Cook, and Prof. Martina Koelbl-Ebert.

\section{References}

Anonymous, 1885, News: The Third International Geological Congress: Nature, v. 32, no. 22, pp. 599-601.

Anonymous, 1888, Congrès Géologique International: Compte Rendu de la 3me Session, Berlin 1885: A.W. Schade's Buchdruckerei (L. Schade), Berlin. 
Anonymous, 1997, Historical summary of the International Geological Congress: General Proceedings of the $30^{\text {th }}$ International Geological Congress, Beijing, August 4-14, 1996, pp. 1-2.

Bassett, M.G., 1979, 100 years of Ordovician Geology: Episodes, v. 8, pp. $18-25$.

Boixereu, E. 2016, Evolución histórica de la cartografía Geológica en España: desde sus orígenes hasta el mapa de Verneuil y Collomb (1864) y Maestre (1865), Ph.D. Politechical University of Madrid.

Bouysse, P., 2013, The Commission for the Geological Map of the World, Genesis and development over one century of existence: Supplement to Bulletin CCGM No. 57, Commemorative centennial issue CCGM/ CGMW 2013 Paris, CGMW.

Choffat, P., 1885-1887, Troisième Séssion du Congrès géologique international: Jornal de Sciencias Mathematicas, Physicas y Naturaes, v. 11, pp. 12-22.

Dewalque, G., 1885, International Geological Congress at Berlín: Science agreement upon the standardization of the geological maps was, v. VI, no. 140 , pp. 520 .

Ellenberger, F., 1999, The First International Geological Congress, Paris, 1878: Episodes, v. 22, pp. 113-117.

Firket, A.D., 1885, Congreso Geológico Internacional: Revista Minera y Metalúrgica, v. 36, pp. 375-377. (Taken from the Revue Universelle Cuyper)

Frazer, P., 1886a, The Work of the International Congress of Geologists, and of its Committees [Philadelphia?]: American Committee [of the International Congress of Geologists].

Frazer, P., 1886b, Résumé of The work of the International Geological Congress, held at Berlin: Proceedings of the American Philosophical Society, v. 23, no. 122, pp. 259-261.

Gilbert, G.K., 1887, The Work of the International Congress of Geologists: The Salem Press, Salem.

Hughes, T.M., 1884, The International Geological Congress Postponed: Geological Magazine (Decade III), v. 1, no. 9, pp. 432.

Nery Delgado, J.F., and Choffat, P., 1884, Rapport de la sous-commission portugaise de nomenclature, en vue du Congrès géologique international devant avoir lieu à Berlin en 1884: Communicações da Commissão dos Trabalhos Geologicos de Portugal, v. 1, Lisboa, Academia Real das Sciencias.

Neumayr, M., 1883, Projet pour la publication d'un Nomenclator Paleontologicus : Rapport présenté à la commission internationale pour l'unification de la nomenclature géologique à la réunion de Zurich le 7 août 1883, Bologne, Fava et Garaguacci.

Renevier, E., 1886, Résultats scientifiques du Congrès géologique international de Berlin et des travaux qui s'y rattachent: Bulletin de la Société Vaudoise des Sciences Naturelles, v. 22.

Schäfer-Weiss D., and Versemann, J., 2005, The influence of Goethe's Farbenlehre on Early Geological Map Colouring: Goethe's contribution to Christian Keferstein's General Charte von Teutschland (1821): Imago Mundi, v. 57, no. 2, pp. 164-184.

Vai, G.B., 2004, The Second International Geological Congress, Bologna, 1881: Episodes, v. 27, pp. 13-20.

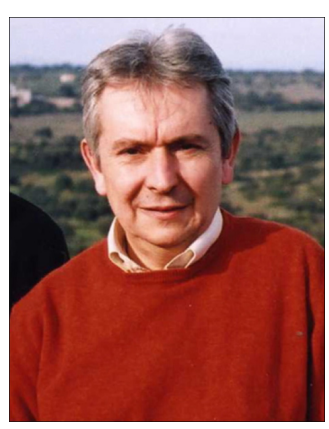

Octavio Puche-Riart is a PhD Mining Engineer and Professor of History of Geology and Mining at the Madrid School of Mines and Energy. He is at present, Assistant Director of the Historical Mining Museum D. Felipe de Borbón y Grecia, member of International Commission on the History of Geological Sciences (IHIGEO-IUGS) since 1994 and honorific member of Spanish Society for Geological and Mining Heritage. He is particularly interested on the mining heritage and history.

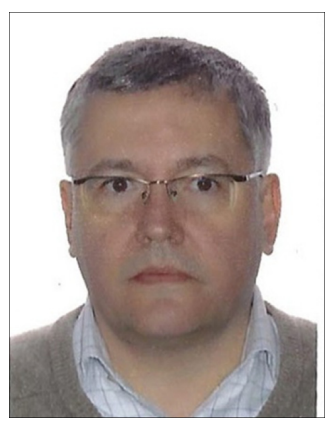

Luis F. Mazadiego is a $\mathrm{PhD}$ in Mining Engineering and Professor at the Madrid School of Mines and Energy (Technical University, UPM). Member of Sociedad Española para la Defensa del Patrimonio Geológico y Minero de España (SEDPGYM) and director of the scientific journal De Re Metallica. Besides is member of INHIGEO-IUGS.

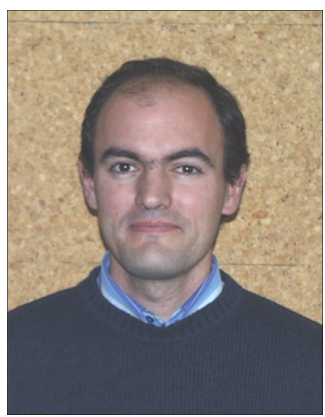

José E. Ortiz is a PhD Mining Engineer and a professor of Geology at the Madrid School of Mines and Energy, Technical University of Madrid. He is the secretary of the Geological Society of Spain. His research is related to stratigraphy, organic geochemistry and palaeoclimatology. 